\title{
PENGUATAN LOCAL WISDOM MASYARAKAT KEPULAUAN DALAM MENCEGAH WABAH MELALUI KKN-DR
}

\author{
Samsul Arifin, Miftahul Alimin, Siti Hartatik, \\ Indah Ulil Firdausiyah, \& Nur Aini \\ Universitas Ibrahimy Situbondo, Indonesia \\ syamsulahasan@ibrahimy.ac.id \\ alimin92miftahul@gmail.com
}

\begin{abstract}
This outreach program aimed to recognize and strengthen local wisdom of the people in Sapudi Island, Madura in preventing plague (tolak-balak). The community service method uses Participatory Action Research (PAR). The results show that the people of Sapudi Island in preventing disease outbreaks include: doing Rokat Pandhaba, Burdah Keliling Kampong, and other ritual or celebration. The purpose of the celebration is to get closer to Allah and to familiarize relationships with the community and the environment in order to avoid disasters and calamities. By doing harmonization between God, human beings, and the environment, people feel that they have achieved meaning in life (meaningfullnees). This paper was useful for developing theories of mental health, psychology, and counseling which are resulted from the values of the locality of the archipelago.
\end{abstract}

Keyword: local wisdom, plague, celebration 


\section{Pendahuluan}

\section{Isu dan Fokus Pengabdian}

Masyarakat kepulauan Nusantara memiliki beberapa kearifan lokal (local wisdom) untuk menolak wabah bencana atau ketika tertimpa bencana alam. Mereka memiliki ketangguhan dalam menghadapi bencana dan mampu bangkit kembali dari keterpurukan akibat bencana. Mereka membuat forum bersama, melalui selamatan adat, untuk saling menguatkan dan memberi dukungan sosial ketika terjadi wabah bencana.

Ritual selamatan ketika untuk menolak wabah yang amat popular di Kepulauan Sapudi antara lain Rokat Pandhaba, burdah keliling, dan Selamatan lainnya. Rokat Pandhaba merupakan doa-doa keselamatan sekaligus sedekah, yang berisi nilai-nilai lokalitas dan religiusitas. Selamatan Rokat ini penting untuk kesehatan mental masyarakat. Menurut hasil penelitian tentang pengaruh Ruwatan terhadap kesehatan, Ruwatan atau Rokat memberikan perubahan yang lebih baik pada masalah mental dan sosial ${ }^{1}$. Begitu pula, Rokat bagi masyarakat

1 S Rahanto, "Pengaruh Ruwatan Murwokolo Terhadap Kesehatan," Penelitian Sistem Kesehatan 15, no. 5 (2012): 282-88; Samsul Arifin and Akhmad Zaini, "Transformative Da'wah Through Counseling for the Career Development of Coffee Farmer Groups in the Tourism Village Banyuwangi," Jurnal Konseling Religi 10, no. 2 (2019): 215-31, https://doi.org/http://dx.doi.org/10.21043/kr.v10i2.6480. 
Pulau Madura sebagai upaya pencegahan terhadap suatu penyakit 2. Bahkan Rokat juga berfungsi sebagai penguatan untuk hidup berkah dan sehat ${ }^{3}$.

Dari sisi konseling komunitas, Selamatan Rokat Pandhaba dapat dijadikan teknik untuk meningkatkan kesehatan mental masyarakat dan dapat sebagai pemulihan untuk mengembalikan kepercayaan masyarakat setelah tertimpa bencana. 4. Dalam konteks pandemi COVID-19, konseling dapat berkonstribusi dalam membantu menyelesaikan masalah yang dihadapi orang yang terdampak COVID19. Konseling memiliki arti penting dalam kondisi bencana yang membutuhkan rehabilitasi, intervensi, dan pertimbangan terapeutik. Karena itu, beberapa regulasi tentang gugus tugas percepatan penangan

${ }^{2}$ Nurwidodo, "Pencegahan Dan Promosi Kesehatan Secara Tradisional Untuk Peningkatan Status Masyarakat Di Sumenep Madura," Jurnal Humanity 1, no. 2 (2006): 96105.

3 Samsul Arifin, "Hidup Berkat Dan Sehat: Kearifan Kiai Pesantren Dalam Memperbaiki Kesehatan Jiwa Masyarakat Dalam Kitab Al-Adzkar Al-Yaumiyyah," in Tradisi Dan Kebudayaan Nusantara, ed. Sumanto Al Qutuby and Izak Y. M. Lattu (Semarang: Lembaga Studi Sosial dan Agama (eLSA) Press, 2019), 58-83; Samsul Arifin, "Menjadi Warga Negara Khaira Ummah Dengan Hidup Sehat Tanpa Korupsi," Jurnal Konseling Religi 9, no. 1 (2018): 39-60, https://doi.org/10.21043/kr.v9i1.3365; Samsul Arifin, "Pengembangan Self-Concept Khaira Ummah Santri Perempuan Menyongsong Era Society 5.0 Perspektif Pengembangan Karier," Hisbab: Jurnal Bimbingan Konseling Dan Dakwah Islam 17, no. 1 (2020): 33-60, https://doi.org/10.14421/hisbah.2020.171-04.

${ }^{4}$ Arifin, "Hidup Berkat Dan Sehat: Kearifan Kiai Pesantren Dalam Memperbaiki Kesehatan Jiwa Masyarakat Dalam Kitab Al-Adzkar Al-Yaumiyyah"; Samsul Arifin, AtTawazun: Psikologi Dan Konseling Berbasis Pesantren Untuk. Membentuk Karakter Khaira Ummah (Malang: Literasi Nusantara, 2020); Ahmad Azaim Ibrahimy and Samsul Arifin, Kiai Fawaid As'ad: Kepribadian, Pemikiran, Dan Perilaku Politik (Situbondo: Tanwirul Afkar, 2018). 
COVID-19 terdapat program pendampingan kesehatan mental dan psikososial. Dari beberapa penelitian juga menunjukkan bahwa tekanan dan kesehatan mental cenderung meningkat setelah COVID-19 5.

Beberapa penelitian konseling yang terkait wabah COVID-19, terdapat kajian yang menawarkan religious e-counseling ${ }^{6,}$ structured letter therapy 7, dan sebagainya. Ada pula yang meneliti dari sisi konseling Islami tentang memperkuat kesehatan mental melalui membangun emosi positif ${ }^{8}$. Dalam konteks dunia pesantren, ada yang

${ }^{5}$ Effiong Anietie Imo et al., "Counselling for Covid-19 Patients: Implications for Social Well-Being," Academicia: An International Multidisciplinary Research Journal 10, no. 5 (2020): 523-28, https://doi.org/10.5958/2249-7137.2020.00261.X; Neha Chaurasia et al., "Covid-19: Psychological Impact of a Pandemic Disease," Research Reports., no. August (2020): 1-12, https://doi.org/10.9777/rr.2020.10003; Menteri Kesehatan, "Keputusan Menteri Kesehatan Republik Indonesia Nomor HK.01.07/Menkes/413/2020 Tentang Pedoman Pencegahan Dan Pengendalian COVID-19” (2020); Menteri Kesehatan Menteri Pendidikan dan Kebudayaan, Menteri Agama and Menteri Dalam Negeri, "Panduan Penyelenggaraan Pembelajaran Pada Tahun Ajaran 2020/2021 Dan Tahun Akademik 2020/2021 Di Masa Pandemi Corona Virus Disease 2019 (Covid-19)" (2020); Samsul Arifin, "Pesantren -Based Counseling in Changing The Behaviour of The Community of Former Bajingan Being Personal Characterless 'Pelopor," UMRAN - International Journal of Islamic and Civilizational Studies 07, no. 03 (2020): 59-75, https://doi.org/https://doi.org/10.11113/umran2020.7n3.439; Panos Vostanis and Chance A Bell, "Counselling and Psychotherapy Post-COVID-19," Counselling and Psychotherapy Research, no. May (2020): 1-5, https://doi.org/10.1002/capr.12325.

${ }^{6}$ Dudy Imanuddin Effendi et al., "Advokasi Psikologis Bagi Masyarakat Terpapar Pandemi Covid-19 Berbasis Religious E-Counseling," 2020, http://digilib.uinsgd.ac.id/id/eprint/30709.

Chunfeng Xiao, “A Novel Approach of Consultation on 2019 Novel Coronavirus ( COVID-19) -Related Psychological and Mental Problems: Structured Letter Therapy," Psychiatry Investig 17, no. 2 (2020): 175-76, https://doi.org/https://doi.org/10.30773/pi.2020.0047.

${ }^{8}$ Fitriah M. Suud et al., "The Role of Islamic Counselling in Pandemic COVID-

19," Konseling Religi Jurnal Bimbingan Konseling Islam 11 (2020): 18-35, 
meneliti tentang "ngaji online" yang mulai semarak digunakan oleh beberapa kiai dan pesantren, penggunaan teknik 'uzlah dan doa serta yang membahas mengusir wabah dengan doa syair li khamsatun 9. Di samping itu terdapat penelitian tentang ketangguhan keluarga sakinah dalam menghadapi pandemi COVID-19 10.

Dari beberapa penelitian, baik tentang Rokat maupun Ruwatan, belum ada yang mengkaji praktik ritual Rokat Pandhaba sebagai tolak balak dari bencana dari perspektif konseling. Padahal ritual Rokat dapat dijadikan teknik dalam konseling komunitas, terutama konseling yang digali dari nilai-nilai religiusitas dan lokalitas.

Konseling termasuk ilmu terapan, karena itu pencarian kearifan lokal (local wisdom) dan memasukkan nilai-nilai keagamaan dalam

https://doi.org/http://dx.doi.org/10.21043/kr.v11i1.7705.

${ }^{9}$ Samsul Arifin and Akhmad Zaini, "Decision of Implementing Uzlah and Gerbat Techniques in Islamic Boarding School as Preparedness Response for Covid-19 Pandemic," Unnes Journal of Public Health 9, no. 2 (2020), https://doi.org/https://doi.org/10.15294/ujph.v9i2.38107; Samsul Arifin, "Dinamika Perubahan Relasi Kiai Santri Pada 'Ngaji Online' Di Masa Pagebluk COVID-19," Jurnal Kependudukan Indonesia 1 (2020): 75-80, https://doi.org/https://doi.org/10.14203/jki.v0i0.538; H. Zuhri, "Pemaknaan Syair Li Khamsatun Di Tengah Pandemi COVID-19 Perspektif Living Islam,” Living Islam: Journal of Islamic Discourses 3 (2020): 149-66, https://doi.org/doi: 10.14421/lijid.v3i1.2272.

${ }^{10}$ Samsul Arifin and Mokhammad Baharun, "Strengthening Resilience of Sakinah Families in New Normal Adaption: Pesantren-Based Counseling Perspective," in Proceedings of the International Conference on Engineering, Technology and Social Science (ICONETOS 2020), vol. 529 (Atlantis Press, 2021), 202-9, https://doi.org/https://doi.org/10.2991/assehr.k.210421.029; Samsul Arifin and Akhmad Zaini, "Social Wellbeing and Collective Happiness ( Study of " Sedekah Selamatan Sîr " on Career Development )," in The 3 Rd International Symposium on Religious Life (ISRL) 2020 (Bogor: EAI, 2021), https://doi.org/10.4108/eai.2-11-2020.2305073. 
konseling sangat penting. Konseling yang diadaptasi dari nilai-nilai spiritual cenderung lebih efektif apalagi dalam situasi pandemi COVID19. Beberapa kalangan menyarankan agar tenaga medis juga diberi bekal dalam layanannya dengan pengetahuan keagamaan yang memadai; terutama yang terkait dengan jenazah COVID-19. Misalnya bagaimana cara memandikan, menyolati, dan menguburkan sesuai dengan agama. Karena itu, integrasi konseling dengan ilmu lainnya merupakan keniscayaan dalam masa pandemic COVID-19 11.

Kerangka teori pada penelitian ini menggunakan perspektif teori konseling indigenous. Konseling indigenous merupakan kajian ilmiah yang menelaah pengetahuan, keterampilan, dan kepercayaan yang dimiliki orang tentang dirinya sendiri dan mengkaji aspek-aspek tersebut dalam konteks alamiahnya ${ }^{12}$. Peneliti menggunakan konseling

11 Chance A Bell et al., "Research in Counselling and Psychotherapy PostCOVID-19," Counselling and Psychotherapy Research, no. June (2020): 1-5, https://doi.org/10.1002/capr.12334; Vostanis and Bell, "Counselling and Psychotherapy Post-COVID-19"; Francesco Chirico and Gabriella Nucera, "An Italian Experience of Spirituality from the Coronavirus Pandemic," Journal of Religion and Health 59 (2020): 21932195; Arifin and Zaini, "Decision of Implementing Uzlah and Gerbat Techniques in Islamic Boarding School as Preparedness Response for Covid-19 Pandemic"; A Samsul and A F Risma, "The Model of Development Therapeutic Speech in the Digital Era: A Study of 'Interpretation of Al- Mishbah ' for Cyber-Counseling Services," in Proceedings of the 19th Annual International Conference on Islamic Studies, AICIS 2019, 1-4 October 2019, Jakarta, Indonesia (EAI, 2020), https://doi.org/10.4108/eai.1-10-2019.2291647.

12 Uichol Kim, Indigenous and Cultural Psyichology (New York,: Springer Science, 2006).

Vo 1. 3 No. 1, A p ril 2021

Samsul Arifin dkk| 116

gurnal Pengabdian Masyarakat 
indegenous dengan pendekatan teori Konseling at-Tawazun 13. Konseling at-tawazun mengacu kepada nilai-nilai islami (fiqh dan tasawuf) serta kearifan lokal pesantren. Pendekatan konseling pesantren ini memiliki karakteristik keharmonisan dan keseimbangan (attawazun) dari berbagai unsur dan potensi yang berada dalam diri konselor, konseli, dan lingkungan serta mengacu kepada kemaslahatan (wisdom-oriented counseling approach) ${ }^{14}$.

Fokus permasalahan yang diulas dalam tulisan ini adalah pengenalan terhadap tradisi dan penguatan kembali kearifan lokal (lokal wisdom) masyarakat Pulau Sapudi Madura dalam mencegah wabah (tolak balak). Tulisan ini penting untuk pengembangan teoriteori kesehatan mental, psikologi, dan konseling yang digali dari nilainilai lokalitas Nusantara.

\section{Metode}

13 Samsul Arifin, "Konseling At-Tawazun (Titik Temu Tradisi Pesantren Dan Konseling)," in Conference Proceedings: Annual International Conference on Islamic Studies (AICIS) XII, 5 - 8 November 2012, Surabaya - Indonesia (Surabaya: UIN Sunan Ampel, 2012), 214967, http://digilib.uinsby.ac.id/id/eprint/7594.

14 Samsul Arifin and Hanik Munfaridah, "Pengembangan Desain Konseling Berbasis Pesantren Dengan Pendekatan Service-Learning," Jurnal Bimbingan Dan Konseling Islam 08, no. 02 (2018): 110-32; Samsul Arifin and Akhmad Zaini, "Dakwah Transformatif Melalui Konseling: Potret Kualitas Kepribadian Konselor Perspektif Konseling AtTawazun," Jurnal Dakwah XV, no. 1 (2014): 137-56, https://doi.org/https://doi.org/10.14421/jd.2014.15107; Arifin and Zaini, "Transformative Da'wah Through Counseling for the Career Development of Coffee Farmer Groups in the Tourism Village Banyuwangi"; Samsul Arifin, "Komunikasi Kiai Pesantren: Pemberdayaan Komunitas Bajingan Perspektif Komunikasi Konseling," in 2nd Proceedings Annual Conference for Muslim Scholars (Surabaya: Kopertais IV, 2018), 330-38. 
Strategi yang digunakan dalam pengabdian masyarakat ini adalah pendekatan penguatan masyarakat berbasis Participatory Rural Appraisal 15. Dengan strategi PRA tersebut diharapkan permasalahan masyarakat dapat direview, dalam hubungannya dengan perencanaan alternatif pemecahan masalah bersama masyarakat sehingga dapat menumbuhkan kesadaran bersama karena mereka terlibat didalamnya.

Adapun pelaksanaan PRA, program akan dilakukan melalui beberapa cara sebagai berikut: Pertama, memberikan pemahaman kepada masyarakat tentang kondisi wabah COVID-19 dan menjelaskan permasalahan terkini yang dihadapi dalam menyatukan visi tersebut. Kedua, menyusun rencana aksi partisipatif bersama warga, yaitu merencanakan kegiatan berdasarkan permasalahan yang ditemukan dari hasil kajian bersama sesuai kebutuhannya. Ketiga, melaksanakan program yang telah disepakati oleh masyarakat. Keempat, menguatkan kearifan lokal masyarakat yang terkait dengan pencegahan wabah atau tolak balak. Kelima, melakukan evaluasi dan refleksi. Keenam, menyusun laporan kegiatan yang menggambarkan kegiatan program

15 M. dkk. Daniel, PRA Participatory Rural Apprisal (Jakarta: Bumi Aksara, 2008); Karen Schoonmaker Freudenberger, Rapid Rural Apprisal (RRA) And Participatory Rural Appraisal (PRA) (Mary Land: CRS, 2018); Samsul Arifin, Akhmad Zaini, and Kautsar Wibawa, "Strengthening Family - Based Local Cultural Values in the Conflicting Area and Marine Ecotourism of Situbondo Indonesia," Journal of Community Development Research (Humanities and Social Sciences) 14, no. 2 (2021): 50-62, https://doi.org/10.14456/JCDRHS.2021.15. 
ini dalam bentuk penulisan naratif.

\section{Hasil dan Diskusi}

\section{Pengenalan Situasi}

Lokasi pengabdian masyarakat ini adalah Pulau Sapudi. Sapudi adalah sebuah pulau di antara gugusan pulau-pulau di sebelah timur Pulau Madura. Secara geografis, Pulau Sapudi berada di wilayah bagian timur Provinsi Jawa Timur dengan jarak kurang lebih 200 km dari Ibu Kota Provisi yakni Surabaya. Koordinat wilayah terletak antara 113o48'10"-113o48'26" Bujur Timur dan antara 7o50'10"-7o56'41" Lintang Selatan. Keadaan topografi wilayah pulau Sapudi merupakan daratan yang bervariasi dengan 44,4\% wilayahnya merupakan lautan dan perbukitan, 30,7\% merupakan dataran rendah dan 24,9\% merupakan dataran tinggi. Ditinjau dari ketinggiannya, pulau Sapudi rata-rata berada pada posisi $253 \mathrm{mdpl}$. Dengan puncak tertinggi 3.287 mdpl (Kecamatan Gayam dan Nonggunong).

Secara administratif, Pulau Sapudi termasuk wilayah Kabupaten Sumenep, Jawa Timur. Di antara gugusan pulau-pulau di sebelah timur Pulau Madura, Sapudi merupakan pulau terluas kedua setelah Pulau Kangean. Pulau Sapudi penduduknya terbanyak. Pulau ini terbagi atas dua kecamatan, yakni Gayam di bagian selatan, dan Nonggunong di bagian utara. 
Letak pulau Sapudi lebih kurang 27 mil laut di sebelah timur pulau Madura dengan luas: 126.686.257 Ha. Sedangkan batas-batas wilayah Pulau Sapudi meliputi, sebelah timur berbatasan dengan Kecamatan Raas, sebelah barat berbatasan dengan Kecamatan Kalianget dan Dungkek, sedangkan sebelah utara berbatasan dengan Kecamatan Masalembu, sementara sebelah selatan berbatasan langsung dengan selat Madura.

Ada pun pembagian pembagian daerah administrasinya pulau Sapudi terbagi menjadi dua kecamatan yaitu Kecamatan Nonggunong dan Kecamatan Gayam. Kecamatan Nonggunong membawahi 8 Desa di antaranya: Desa Nonggunong, Desa Sumber, Desa Talaga, Desa Tanah Merah, Desa Rosong, Desa Sokarami Pesisir, Desa Sokarami Temur, dan Desa Sonok. Sedang Kecamatan Gayam yang ditetapkan sebagai ibukota Sapudi membawahi 10 Desa, dengan nama-nama desanya sebagai berikut: Desa Gayam, di sebalah timur Desa Prambanan, kemudian Desa Gendang Timur, Desa Gendang Barat, Desa Tarebung, Desa Kalowang, Desa Jambuir, Desa Karang Tengah, Desa Nyamplong, dan Desa Pancor.

Sebenarnya pada mulanya Pulau Sapudi hanya mempunyai satu kecamatan saja yaitu Kecamatan Gayam. Sedangkan Kecamatan Nonggunong sendiri diusulkan sebagai kecamatan zelfstanding sudah 
mulai dulu, namun pada tahun 1982 usulan tersebut baru diterima dan kemudian diresmikan sebagai salah satu dari 2 kecamatan yang ada di kepulauan Sapudi.

Sama seperti daerah Madura pada umumnya Pulau Sapudi juga merupakan dataran rendah yang beriklim kering, dan terdiri atas tanah kering, sehingga pertanian di pulau ini tidak terlalu baik ini disebabkan secara teknis pulau ini sangat kering dan membutuhkan air dengan skala yang lebih banyak. Selain itu tanah Pulau Sapudi pada umumnya merupakan tanah tegalan dan sawah tadah hujan, tanah yang seperti ini biasanya hanya dapat di tanami tanaman jagung saja yang di sokong oleh beberapa tanaman yang bisa membantu diantaranya ketela pohon dan palawija.

Keadaan tanah pada umumnya di Pulau Sapudi adalah tanah kering dan berbatu - batu. Adapun pengairannya dapat dikatakan sangat kurang sehingga sebagian besar tanahnya merupakan tanah tegalan yang berbatu-batu. Adapun curah hujan di Pulau Sapudi tidak berbeda dengan daerah-daerah lainnya yang ada di Pulau Madura yaitu termasuk yang kurang hujannya. Sehingga tidak ada tanaman yang bisa dihasilkan selain tanaman jagung, ketela pohon dan palawija. Kondisi yang seperti inilah yang membangun masyarakat Madura umumnya dikenal sebagai masyarakat yang keras, dalam artian mereka dituntut 
untuk bekerja keras apabila mereka ingin menjadi orang yang yang sukses.

\section{Kajian Keadaan Wilayah}

Pada tahap kajian keadaan wilayah, peneliti mengadakan kajian keadaan wilayah untuk mengetahui beberapa problematika dan potensi yang terdapat di masyarakat. Media untuk melakukan ini, antara lain:

a) Silaturrahmi

Setelah mengetahui gambaran umum lokasi kuliah kerja nyata (KKN) yang menjadi tempat pengabdian masyarakat, peneliti selanjutnya melakukan silaturrahmi kepada komunitas masyarakat dampingan. Terutama kepada para guru dan alumni pondok pesantren Salafiyah Syafi'iyah untuk melakukan beberapa problematika masyarakat dan beberapa potensi kearifan lokal.

b) Kegiatan Rotibul Hadad

Kegiatan rutin Rotibul Haddad di beberapa masjid dan mushalla termasuk media peneliti untuk membangun hubungan erat dengan komunitas dampingan. Di samping itu sebagai wahana sistem pengkaderan. Peneliti menggunakan media kegiatan Ratib untuk mengetahui problematika yang menimpa anak-anak ketika terjadi wabah. 
c) Khotmil Qur'an

Kegiatan Khotmil Qur'an dilaksanakan pada setiap hari dikarenakan bertepatan dengan bulan Ramadhan. Pengajian hataman juga sebagai media untuk melakukan pemetaan problematika dan potensi komunitas dampingan. Di samping itu dalam rangka meningkatkan kehidupan masyarakat yang religius. Dalam mengupayakan hal tersebut, peneliti bekerjasama dengan pengurus Ikatan Santri dan Alumni Salafiyah Syafi'iyah (Iksass) Rayon Sapudi.

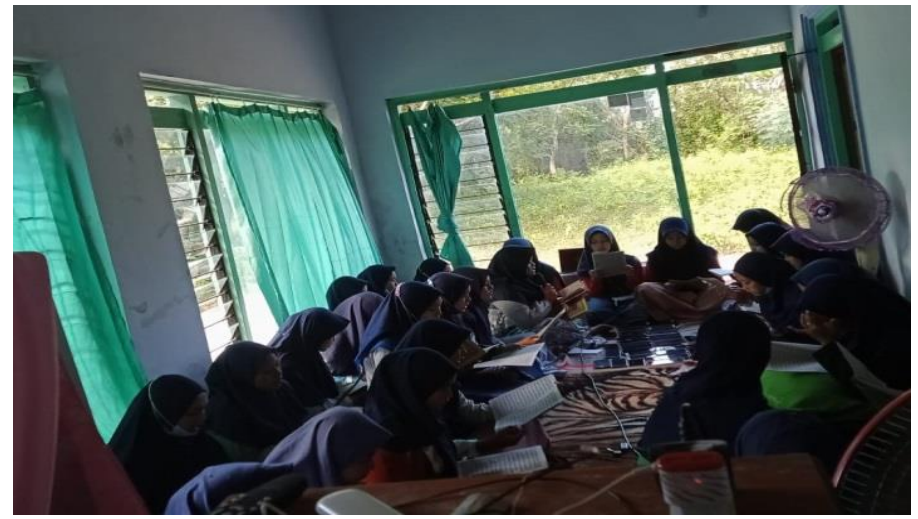

Gambar 1 Kegiatan khatmil qur'an

d) Pembacaan Shalawat

Kegiatan pembacaan shalawat juga sebagai media untuk melakukan hubungan dengan masyarakat yang bagus, untuk mengetahui problematika dan potensi mereka. Kegiatan shalawat tersebut misalnya shalawat berzanji dan shalawat nariyah. Anggota shalawat 
tersebut kebanyakan ibu-ibu. Media tersebut peneliti tempuh untuk mengetahui realitas keadaan ibu-ibu muslimat ketika terjadi wabah.

e) Pengajian Fatayat NU

Pengajian Fatayat NU juga sebagai media untuk melakukan kajian keadaan wilayah. Kami melakukan tersebut untuk mengetahui problematika dan potensi Fatayat NU ketika terjadi wabah.

\section{Menyusun Perencanaan Aksi Secara Partisipatif}

Setelah penelii mengetahui problematika dan potensi masyarakat Sapudi, kemudian peneliti bersama-sama komunitas dampingan menyusun rencana aksi secara partisipatif. Kami melakukan perencanaan ini melalui media kegiatan yang diadakan komunitas dampingan. Rencana aksi yang terkait dengan kearifan lokal masyarakat dalam mencegah wabah.

\section{Melaksanakan Aksi}

Bentuk kegiatan aksi pengabdian masyarakat yang peneliti lakukan pada KKN-DR pada masa pandemic COVID-19 yang berhubungan dengan kearifan masyarakat dalam menghadapi wabah antara lain:

\section{a) Rokat Pandhaba}

Rokat pandhaba adalah upacara kebebasan seorang anak pandhaba dari nasib buruk yang akan menimpanya, serta menjauhkan dari segala 
bentuk mara bahaya yang dapat mengganggu perjalanan hidup di dunia. Tradisi ini dilakukan oleh masyarakat Sapudi dengan maksud dan tujuan agar terhindar dari mala petaka atau musibah.

Rokat pandhaba merupakan tradisi yang mengandung arti atau maksud tersendiri bagi masyarakat di Pulau Sapudi, sehingga tradisi ini masih diselenggarakan dan dipertahankan sampai saat ini. Tradisi ini muncul dari suatu keyakinan ketika ada anak atau orang yang sudah dewasa yang perlu di-pandhaba tetapi tidak d- pandhaba, Anak atau orang tersebut akan selalu diganggu oleh makhluk yang bernama batarakala. Ciri-ciri keturunan yang dikategorikan sebagai keturunan pandhaba ialah anak tunggal laki-laki (pandhaba rato) atau perempuan (pandhaba tang-anteng dhengghi), dua bersaudara, jika satu laki-laki dan satu perempuan (pandhaba mantan/pandhaba kadana kadane),dan banyak lagi pandhaba-pandhaba yang lain. Dalam pelaksanaannya, diperlukan beberapa sesajen ataupun perlengkapan yang harus disiapkan oleh keluarga sebagai penebus anak pandhaba, perlengkapan tersebut juga bisa langsung diganti dengan sejumlah uang. Selain itu alat-alat atau sesajhen yang dibutuhkan memiliki arti yang berbeda ataupun memiliki makna tersendiri dalam ritual tersebut. 
Kearifan lokal dalam menghadapi wabah dalam tradisi selamatan (rokat pandhaba) yang dimana rokat pandhaba ini tidak dilakukan oleh sembarangan orang hanya orang tertentu orang yang wajib melaksanakan rokat pandhaba yang dalam pelaksanaannya kita harus menyiapkan seribu buah, misalnya buah salak beserta tangkainya, simulan beserta tangkainya, mangga beserta tangkainya, dan buah lainnya. Selain itu yang harus ada adalah seribu bunga, seribu duri, air 7 sumur, peralatan dapur, peralatan sawah, pakaian lengkap (mukennah, sarung, baju), serabi dan uang yang sesuai dengan tinggi anak pandhaba. Namun jika peralatan yang dibutuhkan kurang lengkap, maka harus diganti dengan uang yang sesuai dengan kekurangan.

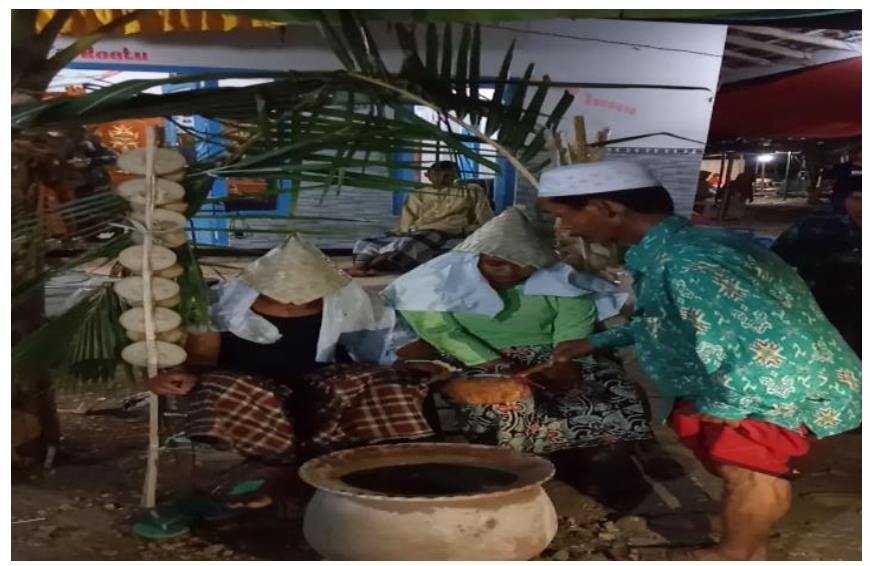

Gambar 2 ritual rokat pandhaba 
Sedangkan untuk proses intinya adalam serangkaian upacara untuk pemandian pandhaba, sebelum dimandikan, biasanya proses awalnya adalah sukuran dengan mengundang para tetangga atau sering dikenal arasol, selanjutnya mamaca, atau bisa juga digantikan dengan pembacaan ayat-ayat suci Al-Qur'an (hataman). Setelah itu anak akan dimandikan oleh keluarganya diwaktu fajar subuh. Biasanya akan dimandikan ditengah-tengah halaman atau ditengah sawah. Ketika akan di mandikan, anak itu akan diselimuti oleh kain putih (kain kafan) dan tangannya di ikat oleh labhai kemudian akan di mandikan oleh keluarganya dengan air 7 sumur dan seribu bunga yang tadi.

Mamaca pada tradisi ini adalah seni vokal madura yang ada persamaannya dengan seni macopat. Mamaca berarti membaca kitab (teks) cerita dengan cara ekejhungngaghi (ditembhangkan), dan sifatnya kondisional. Semisal ketika seni mamaca ini menjadi pengiring pelaksanaan upacara tradisi rokat pandhaba, maka teks atau alur ceritanya adalah tentang pandhaba. Sedangkan maksud dari pengguanaan kain kafan merupakan tanda kerendahan hati karena mati hanya membawa kain bukan membawa benda yang lain. Labhai yang di ikatkan memiliki arti sebagai pengikat bahwa hidup harus terkontrol. Bunga yang telah dicampur yang digunakan untuk 
memandikan anak pandhaba memiliki arti tentang harapan keluarga agar anak pandhaba tersebut nantinta terlepas dari kekangan ancaman yang menyelimuti anak pandhaba, serta memiliki perilaku yang harum (bermartabat) dan berguna bagi kehidupan masyarakat yang umum.

Target ketercapaian dan harapan dalam pelaksanaan rokat pandhaba adalah agar anak tersebut terhindar dari malaprtaka dan musibah. Selain itu, tradisi ini dalah bentuk kiasan agar anak tidak salah didikan. Seperti contohnya anak ontang-anteng, saking sayangnya dan terlalu di manja oleh orang tuanya, anak tersebut dikhawatirkan tidak memiliki tatakrama dan sopan santun sehingga jika dia sudah dewasa akan menjadi anak yang nakal. Jika sudah demikian, tentunya hidup anak tersebut akan selalu menemui musibah. Selain itu tradisi ini adalah bentuk kiasan untuk penyucian diri seorang anak dalam perjalanan hidupnya tidak mengalami masalah dan selalu berada dijalan kebenaran (jalan yang di ridhai Allah SWT).

\section{b) Burdah Keliling}

Kearifan lokal "Burdah Keliling" sebagai upaya mencegah Covid-19 guna menanamkan rasa spiritualisme masyarakat. Karena masyarakat meyakini bahwasanya nilai religiusitas seseorang berpengaruh tidak hanya terhadap perilaku individu akan tetapi 
kehidupan bersama tersebut. Sasaran kami dalam burdah keliling ini adalah bapak-bapak yang notabene memiliki andil yang sangat besar dalam mengamankan desa dari mara bahaya ataupun penyakit seperti wabah Covid-19.

Kegiatan ini dilaksanakan pada malam hari yang diikuti oleh peserta KKN, aparat dan pemuda-pemudi desa dengan menambah iman dan taqwa kepada Tuhan dengan bacaan qosidah burdah keliling desa untuk mendoakan kemakmuran desa dan juga terlepas dari mara bahaya maupun penyakit khususnya masa pandemi.

\section{c) Selametan}

Beberapa selamatan, misalnya molang are yaitu selamatan anak baru lahir. Kegiatan ini dilaksanakan agar anak yang baru lahir selamat dan terhindar dari mara bahaya dan musibah

Tradisi berjamaah atau kumpul bersama-sama pada acara selamatan, termasuk budaya masyarakat pedesaan. Dari perspektif konseling, salah satu manfaat kumpul bersama-sama adalah saling melakukan penguatan (reinforcement). Teori penguat (reinforcement theory) menerangkan sikap, dimana ada kecenderungan atau kesediaan seseorang untuk bertingkah laku tertentu kalau menghadapi suatu rangsangan tertentu. Dengan demikian seseorang yang sedang 
berduka bila mendapat rangsangan motivasi untuk bangkit bersama dari keterpurukan maka ia akan cenderung untuk bangkit pula Begitu pula, menurut teori fasilitasi sosial (social facilitation): orang akan tampil lebih baik ketika ia berada di tengah-tengah orang lain daripada ketika sendirian. Kehadiran orang lain dapat menjadi pendorong untuk bangkit dari keterpurukan. Fasilitasi sosial terjadi ketika orang lain yang hadir juga mengerjakan kegiatan serupa.

Menurut Drive Theory, kehadiran orang lain dapat membawa dampak positif (dengan teori fasilitasi sosial) atau malah kinerjanya akan buruk (teori inhibisi sosial). Kehadiran orang lain menyebabkan seseorang berada pada kondisi siaga sehingga terjadi stimulus berupa motivasi. Stimulus tersebut berfungsi sebagai pendorong (drive) munculnya respon dominan pada situasi tersebut. Jika respon dominan benar (perilaku terasa mudah), maka kehadiran orang lain dapat menyebabkan peningkatan performa. Jika respon salah (sulit) maka kehadiran orang lain akan dapat menurunkan performa ${ }^{16}$

Dari sisi konseling, kegiatan berjamaah suatu komunitas merupakan suatu kekuatan yang luar biasa untuk saling memberi dukungan dan kerjasama untuk bangkit kembali. Dukungan sosial dan kepedulian

16 S.W Sarwono, Psikologi Sosial (Jakarta: Salemba Humanika, 2009); Shelley E. Taylor, Letitia Anne Peplau, and David O. Sears, Social Psychology (New Jersey: Pearson, 2003); Kenneth S Bordens and Irwin A. Horowitz, Social Psychology (Indiana: Freeload Press, 2008).

Vol. 3 No. 1, A pril 2021

Samsul Arifin dkk| 130 gurnal Pengabdian Masyarakat 
terhadap lingkungan dapat membantu kesehatan mental dan sebagai pendorong perilaku kita untuk kembali pulih dan berubah menjadi lebih baik. Dari beberapa penelitian, kesehatan mental dengan membangun ketahanan seseorang ini merupakan target utama dari konseling terhadap orang yang terkena dampak bencana COVID-19 17

Dari penelitian lainnya, predictor utama dari ketahanan dan kesejahteraan konseli yang terkena dampak COVID-19 adalah kekuatan dan kebajikan. Umpamanya, kerendahan hati, rasa syukur, pengampunan, dan perhatian ${ }^{18}$. Penelitian lain, dilakukan di Turki yang mencoba mengeksploirasi penyembuhan dalam konteks budaya; yang menggabungkan ilmu kedokteran, pskiterapy, dan antropologi. Penelitian tersebut menghasilkan temuan, masyarakat Turki melakukan pengobatan ke tabib tradisional dan sembuh dari penyakitnya karena faktor utamanya sikap tawakkal kepada Allah ${ }^{19}$.

17 Robert F Kushner, "What COVID-19 Is Teaching Us About Counseling for Weight Management," Obesity 00, no. 00 (2020): 1-2, https://doi.org/10.1002/oby.22988; V Sunitha et al., "From Epidemic to Pandemic- Covid-19- Psychological, Social and Environmental Impact- A Qualitative Study," International Journal of Advanced Science and Technology 28, no. 7 (2020): 4883-93.

${ }^{18}$ Bell et al., "Research in Counselling and Psychotherapy Post-COVID-19."

19 Y Canel Çınarbaş, D., Tuna, E. \& Ar-Karci, "Turkish Muslim Healers: A Qualitative Investigation of Hocas and Their Methods," Journal of Religion and Health 59 (2020): 2397-2413, https://doi.org/https://doi.org/10.1007/s10943-019-00885-9. 


\section{Kesimpulan}

Masyarakat Kepulauan Sapudi dalam menghadapi wabah memiliki kearifan lokal. Antara lain: melakukan Rokat Pandhaba, Burdah Keliling Kampong, dan Selamatan lainnya. Tujuan selamatan tersebut untuk mendekatkan diri kepada Allah atau membangun kembali relasi dengan Tuhan. Di samping itu untuk membangun kembali relasi sosial dengan masyarakat dan lingkungan agar terhindar dari bencana dan malapetaka. Dengan melakukan harmonisasi antara Tuhan, sesama manusia, dan lingkungan tersebut; masyarakat merasa meraih kebermaknaan hidup (meaningfullnees). Tulisan ini berguna untuk pengembangan teori kesehatan mental, psikologi, dan konseling yang digali dari nilai-nilai lokalitas Nusantara.

\section{Ucapan Terima Kasih}

Peneliti mengucapkan terima kasih kepada K.H.R. Ach. Azaim Ibrahimy, Pengasuh Pondok Pesantren Salafiyah Syafi'iyah Sukorejo Situbondo, Lembaga Penelitian dan Pengabdian Kepada Masyarakat (LP2M), dan panitia KKN-DR Universitas Ibrahimy.

\section{Konstribusi Penulis}

Artikel ini berasal dari beberapa laporan Kuliah Kerja Nyata Dari Rumah (KKN-DR) masa pandemi Covid-19 tahun 2021 kelompok 7. Yang berkonstribusi dalam artikel ini (1) Samsul Arifin sebagai Dosen 
Pembimbing Lapangan (DPL) dan penulis artikel. Sedang mahasiswa yang melakukan pendampingan dan mencari data, antara lain: Siti Hartatik, Nur Aini, dan Indah Ulil Firdausiyah. KKN-DR kelompok 7 di Kecamatan Gayam, Sapudi terdapat 8 peserta yang berasal dari desa yang berbeda dan kegiatannya kerap bersamaan tapi laporannya perindividu. Karena itu, beberapa laporan $\mathrm{KKN}$ terdapat kesamaan kegiatan.

\section{Daftar Pustaka}

Arifin, Samsul. At-Tawazun: Psikologi Dan Konseling Berbasis Pesantren Untuk Membentuk Karakter Khaira Ummah. Malang: Literasi Nusantara, 2020.

—. "Dinamika Perubahan Relasi Kiai Santri Pada 'Ngaji Online' Di Masa Pagebluk COVID-19." Jurnal Kependudukan Indonesia 1 (2020): 75-80. https://doi.org/https://doi.org/10.14203/jki.v0i0.538.

—. "Hidup Berkat Dan Sehat: Kearifan Kiai Pesantren Dalam Memperbaiki Kesehatan Jiwa Masyarakat Dalam Kitab Al-Adzkar Al-Yaumiyyah.” In Tradisi Dan Kebudayaan Nusantara, edited by Sumanto Al Qutuby and Izak Y. M. Lattu, 58-83. Semarang: Lembaga Studi Sosial dan Agama (eLSA) Press, 2019. 
In Conference Proceedings: Annual International Conference on Islamic Studies (AICIS) XII, 5 - 8 November 2012, Surabaya - Indonesia, 2149-67. Surabaya: UIN Sunan Ampel, 2012. http://digilib.uinsby.ac.id/id/eprint/7594.

—. "Menjadi Warga Negara Khaira Ummah Dengan Hidup Sehat Tanpa Korupsi.” Jurnal Konseling Religi 9, no. 1 (2018): 39-60. https://doi.org/10.21043/kr.v9i1.3365.

-. "Pengembangan Self-Concept Khaira Ummah Santri Perempuan Menyongsong Era Society 5.0 Perspektif Pengembangan Karier." Hisbah: Jurnal Bimbingan Konseling Dan Dakwah Islam 17, no. 1 (2020): 33-60. https://doi.org/10.14421/hisbah.2020.171-04.

- "Pesantren -Based Counseling in Changing The Behaviour of The Community of Former Bajingan Being Personal Characterless 'Pelopor."” UMRAN - International Journal of Islamic and Civilizational Studies 07, no. 03 (2020): 59-75. https://doi.org/https://doi.org/10.11113/umran2020.7n3.439.

Arifin, Samsul, and Mokhammad Baharun. "Strengthening Resilience of Sakinah Families in New Normal Adaption: Pesantren-Based Counseling Perspective." In Proceedings of the International Conference on Engineering, Technology and Social Science (ICONETOS 2020), 529:202-9. Atlantis Press, 2021. https://doi.org/https://doi.org/10.2991/assehr.k.210421.029.

Arifin, Samsul, and Hanik Munfaridah. "Pengembangan Desain Konseling Berbasis Pesantren Dengan Pendekatan Service-Learning." Jurnal Bimbingan Dan Konseling Islam 08, no. 02 (2018): 110-32.

Arifin, Samsul, and Akhmad Zaini. "Dakwah Transformatif Melalui Konseling: Vol. 3 No. 1, A pril 2021 Samsul Arifin dkk| 134 gurnal Pengabdian Masyarakat 
Potret Kualitas Kepribadian Konselor Perspektif Konseling At-Tawazun.” Jurnal Dakwah XV, no. 1 (2014): 137-56. https://doi.org/https://doi.org/10.14421/jd.2014.15107.

- "Decision of Implementing Uzlah and Gerbat Techniques in Islamic Boarding School as Preparedness Response for Covid-19 Pandemic.” Unnes Journal of Public Health 9, no. 2 (2020). https://doi.org/https://doi.org/10.15294/ujph.v9i2.38107.

—. "Social Wellbeing and Collective Happiness ( Study of " Sedekah Selamatan Sîr " on Career Development )." In The 3 Rd International Symposium on Religious Life (ISRL) 2020. Bogor: EAI, 2021. https://doi.org/10.4108/eai.2-11-2020.2305073.

- "Transformative Da'wah Through Counseling for the Career Development of Coffee Farmer Groups in the Tourism Village Banyuwangi." Jurnal Konseling Religi 10, no. 2 (2019): 215-31. https://doi.org/http://dx.doi.org/10.21043/kr.v10i2.6480.

Arifin, Samsul, Akhmad Zaini, and Kautsar Wibawa. "Strengthening Family Based Local Cultural Values in the Conflicting Area and Marine Ecotourism of Situbondo Indonesia." Journal of Community Development Research (Humanities and Social Sciences) 14, no. 2 (2021): 50-62. https://doi.org/10.14456/JCDRHS.2021.15.

Bell, Chance A, Sarah A Crabtree, Eugene L Hall, and Steven J Sandage. "Research in Counselling and Psychotherapy Post-COVID-19." Counselling and Psychotherapy Research, no. June (2020): 1-5. https://doi.org/10.1002/capr.12334. 
Bordens, Kenneth S, and Irwin A. Horowitz. Social Psychology. Indiana: Freeload Press, 2008.

Canel Çınarbaş, D., Tuna, E. \& Ar-Karci, Y. "Turkish Muslim Healers: A Qualitative Investigation of Hocas and Their Methods." Journal of Religion and Health 59 (2020): 2397-2413.

https://doi.org/https://doi.org/10.1007/s10943-019-00885-9.

Chaurasia, Neha, Anup Singh, Indramani Lal Singh, Ashish, Trayambak Tiwari, and Tara Singh. "Covid-19: Psychological Impact of a Pandemic Disease." Research Reports., no. August (2020): 1-12. https://doi.org/10.9777/rr.2020.10003.

Daniel, M. dkk. PRA Participatory Rural Apprisal. Jakarta: Bumi Aksara, 2008.

Effendi, Dudy Imanuddin, Dede Lukman, Devi Eryanti, and Sitta Resmiyanti Muslimah. "Advokasi Psikologis Bagi Masyarakat Terpapar Pandemi Covid19 Berbasis Religious E-Counseling,” 2020. http://digilib.uinsgd.ac.id/id/eprint/30709.

Francesco Chirico, and Gabriella Nucera. “An Italian Experience of Spirituality from the Coronavirus Pandemic." Journal of Religion and Health 59 (2020): 2193-2195.

Freudenberger, Karen Schoonmaker. Rapid Rural Apprisal (RRA) And Participatory Rural Appraisal (PRA). Mary Land: CRS, 2018.

Ibrahimy, Ahmad Azaim, and Samsul Arifin. Kiai Fawaid As'ad: Kepribadian, Pemikiran, Dan Perilaku Politik. Situbondo: Tanwirul Afkar, 2018.

Imo, Effiong Anietie, Nseobot Ime Robson, Frank Edidiong Ime, Edet Akpan 
Udemeobong, Soomro Mansoor Ahmed, Km Ashifa, Dinnoo Vinesh, and Simeon Ikoroha Innocent. "Counselling for Covid-19 Patients: Implications for Social Well-Being." Academicia: An International Multidisciplinary Research Journal 10, no. 5 (2020): 523-28. https://doi.org/10.5958/22497137.2020.00261.X.

Kesehatan, Menteri. Keputusan Menteri Kesehatan Republik Indonesia nomor HK.01.07/menkes/413/2020 tentang Pedoman Pencegahan dan Pengendalian COVID-19 (2020).

Kim, Uichol. Indigenous and Cultural Psyichology. New York,: Springer Science, 2006.

Kushner, Robert F. "What COVID-19 Is Teaching Us About Counseling for Weight Management." Obesity 00, no. 00 (2020): 1-2. https://doi.org/10.1002/oby.22988.

Menteri Pendidikan dan Kebudayaan, Menteri Agama, Menteri Kesehatan, and Menteri Dalam Negeri. Panduan Penyelenggaraan Pembelajaran Pada Tahun Ajaran 2020/2021 dan Tahun Akademik 2020/2021 di Masa Pandemi Corona Virus Disease 2019 (Covid-19) (2020).

Nurwidodo. "Pencegahan Dan Promosi Kesehatan Secara Tradisional Untuk Peningkatan Status Masyarakat Di Sumenep Madura." Jurnal Humanity 1, no. 2 (2006): 96-105.

Rahanto, S. "Pengaruh Ruwatan Murwokolo Terhadap Kesehatan." Penelitian Sistem Kesehatan 15, no. 5 (2012): 282-88.

Samsul, A, and A F Risma. "The Model of Development Therapeutic Speech in the Digital Era: A Study of ' Interpretation of Al- Mishbah ' for Cyber- 
Counseling Services." In Proceedings of the 19th Annual International Conference on Islamic Studies, AICIS 2019, 1-4 October 2019, Jakarta, Indonesia. EAI, 2020. https://doi.org/10.4108/eai.1-10-2019.2291647.

Sarwono, S.W. Psikologi Sosial. Jakarta: Salemba Humanika, 2009.

Shelley E. Taylor, Letitia Anne Peplau, and David O. Sears. Social Psychology. New Jersey: Pearson, 2003.

Sunitha, V, G Anburaj, M Sandra Carmel Sophia, and G Gopichand. "From Epidemic to Pandemic- Covid-19- Psychological, Social and Environmental Impact- A Qualitative Study." International Journal of Advanced Science and Technology 28, no. 7 (2020): 4883-93.

Suud, Fitriah M., Abdul Gaffar, Kana Safrina Rauzi, and Moh. Toriqul Chaer. "The Role of Islamic Counselling in Pandemic COVID-19." Konseling Religi Jurnal Bimbingan Konseling Islam 11 (2020): 18-35. https://doi.org/http://dx.doi.org/10.21043/kr.v11i1.7705.

Vostanis, Panos, and Chance A Bell. "Counselling and Psychotherapy PostCOVID-19." Counselling and Psychotherapy Research, no. May (2020): 1-5. https://doi.org/10.1002/capr.12325.

Xiao, Chunfeng. "A Novel Approach of Consultation on 2019 Novel Coronavirus ( COVID-19) -Related Psychological and Mental Problems: Structured Letter Therapy." Psychiatry Investig 17, no. 2 (2020): 175-76. https://doi.org/https://doi.org/10.30773/pi.2020.0047.

Zuhri, H. "Pemaknaan Syair Li Khamsatun Di Tengah Pandemi COVID-19 Perspektif Living Islam." Living Islam: Journal of Islamic Discourses 3 (2020): 149-66. https://doi.org/doi: 10.14421/lijid.v3i1.2272.. 